\title{
Adaptive Model of Wastewater Aeration Tank
}

\author{
Andris Sniders ${ }^{1}$, Aigars Laizans ${ }^{2},{ }^{1-2}$ Latvia University of Agriculture, Faculty of Engineering, \\ Institute of Agricultural Energetics
}

\begin{abstract}
The paper discusses the methodology of oxygen transfer virtual simulation in a wastewater biological treatment process, using the MATLAB/SIMULINK technology. A selftuning adaptive model of a wastewater aeration tank, as a nonstationary object, with variable time dependent sensitivity and inertia indexes, as the functions of input variable - air pneumatic supply capacity $L_{g}(t)\left(\mathrm{m}^{3} / \mathrm{min}\right)$, output variable - dissolved oxygen concentration $\mathbf{C}(\mathrm{t})\left(\mathrm{g} / \mathrm{m}^{3}\right)$ and oxygen expenditure, as a load $-\mathbf{q}(\mathrm{t})$ (g/min), required for wastewater complete purification, is expounded. Virtual models, applying Laplace transforms and SIMULINK blocks library, are composed in order to compare the transient processes of dissolved oxygen concentration in the simplified stationary model with constant sensitivity and inertia coefficients, and in the non-stationary model with variable sensitivity and inertia indexes. The simulation block-diagram for non-stationary model adoption to the variable parameters is developed, using informative links from input variable $L_{g}(t)$, from variable load $q(t)$ and feedback from output variable $C(t)$ as inputs of calculation modulus, allowing to instantly re-calculate the variable indexes during simulation time. Comparison of the simplified stationary model and the non-stationary model shows that the simulation results of oxygen transfer differ up to $50 \%$.
\end{abstract}

Keywords - Modelling, oxygen, self-tuning adaptive model, sensitivity and inertia indexes, wastewater aeration tank

\section{INTRODUCTION}

Wastewater aeration process development is a major task in wastewater treatment improvement aimed at increasing the process output quality and overall energy savings. These tasks call for deeper investigation of the oxygen transfer process in the wastewater aeration tank. The actual problems and tasks on the subject of the development of the wastewater treatment technology, efficiency and process automatic control have been widely investigated and discussed [1, 2, 3, 4].

The optimal regulation of air blowers capacity in order to reach the maximum efficiency is the major and most important activity on the way to increase the overall economic feasibility of municipal wastewater biological treatment [2, 3, 5].

For mathematical modelling of transient process in a wastewater aeration tank as an inertial object, the ordinary and partial differential equations are used [6].

The analyses of the expressions for the static indexes of input-output link and load-output link prove that the wastewater aeration tank is a non-stationary object with variable steady-state and dynamic parameters [7].

The dynamic process of oxygen transfer may be described by one-dimension model because of an even air distribution all over the aeration tank surface, if membrane type air diffusers are used [8, 9]. Thus, the aeration tank of the biological wastewater treatment system may be considered as the first order control object with one variable impact at the input - the air blower capacity, one output variable to control - oxygen concentration, and the main perturbation as a load-oxygen consumption.

The wastewater aeration tank is a typical non-linear and non-stationary object with time dependent sensitivity indexes (gains) and inertia indexes (time constants) [8, 9]. The transient characteristics of this object are described by nonlinear \& non-stationary differential equations, mathematical analyses of which are problematic. The use of the simplification of mathematical models, applying the process linearization and "freezing" of variable coefficients produces an incorrect result.

Virtual analyses, applying the MATLAB/SIMULINK modelling technology, makes it possible to compile simulation models without simplifications and, therefore, make it possible to obtain the transient characteristics with substantially higher accuracy because of automatic variations of the variable sensitivity and inertia indexes during the simulation process. For this purpose, the on-line continuous links and feedbacks should be employed [10].

\section{MATHEMATICAL MODELS OF WASTEWATER AERATION TANK}

The research object is the wastewater aeration tank model with built-in equipment for uniform distribution of atmospheric air, developed in the SIMULINK environment. The simulated object's sensitivity and inertia indexes are recalculated instantly during simulation as the functions of input and output parameters, taking into account physical parameters of the object and perturbations as a variable load.

Two different models of wastewater aeration tank are compared: 1) the stationary linear model with constant transfer coefficients and time constants; 2) the non - stationary model with variable time dependent sensitivity and process inertia indexes. The mathematical models, simulation blockdiagrams and characteristics of the research object are presented in the paper.

The steady-state equations and the transfer functions of the wastewater aeration tank are composed using mathematical analyses, operator mathematics and Laplace transforms. Transient process simulation is performed using SIMULINK. Variable sensitivity and inertia indexes of the wastewater aeration tank are calculated, applying analytical and empirical expressions.

For simplicity, the oxygen transfer in wastewater aeration tank is analysed as a process, where oxygen concentration in wastewater changes uniformly with time, not position. Then 
the transient oxygen transfer can be described by the ordinary differential equations. Using Laplace transforms to differential equations, the operator equations and the transfer functions were obtained for transient process simulation as a function of input variables and parameters of wastewater and aeration tank.

The simplified steady-state equation of the wastewater aeration tank is as follows [9]:

$$
C=C_{O x}(T, h,)-\frac{q \cdot k_{1}\left(h, \lambda_{d}, \sigma_{s}\right)}{L_{g} \cdot k_{2}(T, h)},
$$

where $\mathrm{C}_{\mathrm{Ox}}(\mathrm{T}, \mathrm{h})$ - oxygen solubility in wastewater, $\mathrm{g} / \mathrm{m}^{3}$; $\mathrm{T}$ - wastewater temperature, ${ }^{0} \mathrm{C} ; \mathrm{h}$ - submerging depth of air diffusors, $\mathrm{m} ; \mathrm{q}=\mathrm{Q}\left(\mathrm{L}_{\mathrm{a}}-\mathrm{L}_{\mathrm{t}}\right)$ - oxygen consumption necessary for wastewater complete treatment as a load, $\mathrm{g} / \mathrm{min}$; $\mathrm{Q}-$ wastewater afflux, $\mathrm{m}^{3} / \mathrm{min} ; \mathrm{L}_{\mathrm{a}}$ - oxygen demand for total pollution treatment, $\mathrm{g} / \mathrm{m}^{3} ; \mathrm{L}_{\mathrm{t}}$ - oxygen demand in effluent wastewater, $\mathrm{g} / \mathrm{m}^{3} ; \mathrm{L}_{\mathrm{g}}$ - air capacity supplied to aeration tank, $\mathrm{m}^{3} / \mathrm{min} ; \mathrm{k}_{1}\left(\mathrm{~h}, \lambda_{\mathrm{d}}, \sigma_{\mathrm{s}}\right)$ - coefficient, which estimates influence of aeration unit constructive parameters on the oxygen concentration; $\lambda_{\mathrm{d}}-$ air flow intensity through one disk diffuser, $\mathrm{m}^{3} / \mathrm{h} ; \sigma_{\mathrm{s}}-$ density of disk diffusers on the aeration tank floor area; $\mathrm{k}_{2}(\mathrm{~T}, \mathrm{~h})$ - coefficient, taking into account the impact of activated sludge on oxygen transfer.

\section{A. Linear Stationary Model of Wastewater Aeration}

Initial conditions of the operation area of the research object are as follows: $\mathrm{C}=\mathrm{C}_{0}=$ const., $\mathrm{L}_{\mathrm{g}}=\mathrm{L}_{\mathrm{go}}=$ const., $\mathrm{q}=\mathrm{q}_{0}$ $=$ const. All constructive parameters of the aeration tank are unchangeable and wastewater temperature is constant $(\mathrm{T}=$ $\mathrm{T}_{0}=$ const.). Expanding equation (1) to Talor series, a linear steady-state model of aeration tank is obtained:

$$
C=C_{0}+\frac{\partial C}{\partial L_{g}} \cdot \Delta L_{g}+\frac{\partial C}{\partial q} \cdot \Delta q=C_{0}+K_{a} \cdot \Delta L_{g}+K_{q} \cdot \Delta q,
$$

where $\Delta \mathrm{L}_{\mathrm{g}}-$ variations of input impact $\mathrm{L}_{\mathrm{g}}$ (air blower capacity) around the initial value $\mathrm{L}_{\mathrm{go}}, \mathrm{m}^{3} / \mathrm{min} ; \Delta \mathrm{q}$ - variations of load impact $\mathrm{L}_{\mathrm{g}}$ (air supply capacity) around the initial value $\mathrm{q}_{0}, \mathrm{~g} / \mathrm{min}$.

Transfer coefficient (gain) for input-output link $\left(\Delta \mathrm{L}_{\mathrm{g}} \rightarrow\right.$ $\Delta \mathrm{C}_{\mathrm{a}}$ ) is equal to partial derivative $\partial \mathrm{C} / \partial \mathrm{L}_{\mathrm{g}} \approx \Delta \mathrm{C}_{\mathrm{a}} / \Delta \mathrm{L}_{\mathrm{g}}$ :

$$
K_{a_{o}}=\frac{\Delta C_{a}}{\Delta L_{g}}=\frac{q_{0} \cdot k_{10}\left(h, \lambda_{d o}, \sigma_{s}\right)}{L_{g 0}{ }^{2} \cdot k_{2}\left(T_{0}, h\right)} .
$$

Transfer coefficient (gain) for load -output link $(\Delta \mathrm{q} \rightarrow$ $\Delta \mathrm{C}_{\mathrm{q}}$ ) is equal to partial derivative $\partial \mathrm{C} / \partial \mathrm{q} \approx \Delta \mathrm{C}_{\mathrm{q}} / \Delta \mathrm{q}$ :

$$
K_{q_{o}}=\frac{\Delta C_{q}}{\Delta q}=-\frac{k_{10}\left(h, \lambda_{d 0}, \sigma_{s}\right)}{L_{g 0} \cdot k_{2}\left(T_{0}, h\right)} .
$$

Initial conditions, constant parameters of aeration tank and wastewater, and alteration area of variables for modelling are as follows: $\mathrm{L}_{\mathrm{go}}=60 \mathrm{~m}^{3} / \mathrm{min} ; \mathrm{q}_{0}=900 \mathrm{~g} / \mathrm{min} ; \mathrm{C}_{0}=2 \mathrm{~g} / \mathrm{m}^{3} ; \mathrm{T}=$
$\mathrm{T}_{0}=10^{0} \mathrm{C} ; \mathrm{h}=4 \mathrm{~m} ; \sigma_{\mathrm{s}}=0.063 ; \lambda_{\mathrm{do}}=1.5 \mathrm{~m}^{3} / \mathrm{h} ; \mathrm{L}_{\mathrm{gmin}}=40 \mathrm{~m}^{3} / \mathrm{min} ;$ $\mathrm{L}_{\text {gmax }}=80 \mathrm{~m}^{3} / \mathrm{min} ; \mathrm{q}_{\min }=600 \mathrm{~g} / \mathrm{m}^{3} ; \mathrm{q}_{\max }=1200 \mathrm{~g} / \mathrm{m}^{3}$.

Using expressions from the publication [9] and the formulas $(3,4)$, calculation results for the linear model were obtained: oxygen solubility $\mathrm{C}_{\mathrm{ox}}=13.0 \mathrm{~g} / \mathrm{m}^{3}$; correction coefficients $\mathrm{k}_{1 \mathrm{o}}=1.12, \mathrm{k}_{2}=1.53$; transfer coefficients $\mathrm{K}_{\mathrm{ao}}=$ $0.18\left(\mathrm{~g} / \mathrm{m}^{3}\right) /\left(\mathrm{m}^{3} / \mathrm{min}\right), \mathrm{K}_{\mathrm{qo}}=-0.012\left(\mathrm{~g} / \mathrm{m}^{3}\right) /(\mathrm{g} / \mathrm{min})$.

Applying Laplace transforms for differential equations of the aeration tank [9], the transfer functions of the stationary model for transient process simulation have been compiled.

Transfer function for input-output link $\left(\Delta \mathrm{L}_{\mathrm{g}} \rightarrow \Delta \mathrm{C}_{\mathrm{a}}\right)$ :

$$
W_{a}(s)=\frac{\Delta C_{a}(s)}{\Delta L_{g}(s)}=\frac{K_{a_{0}}}{T_{a_{0}} \cdot s+1},
$$

where $\mathrm{T}_{\mathrm{ao}}-$ mean value of the time constant of the aeration tank for input-output link, min; $\Delta \mathrm{C}_{\mathrm{a}}(\mathrm{s})$ - Laplace transform of oxygen concentration change as a function of the air blower capacity change, $\mathrm{g} / \mathrm{m}^{3} ; \Delta \mathrm{L}_{\mathrm{g}}(\mathrm{s})$ - Laplace transform of the air blower capacity change, $\mathrm{m}^{3} / \mathrm{min}$; $\mathrm{s}$ - Laplace variable, $\mathrm{min}^{-1}$.

Transfer function for load-output link $\left(\Delta \mathrm{q} \rightarrow \Delta \mathrm{C}_{\mathrm{a}}\right)$ :

$$
W_{q}(s)=\frac{\Delta C_{q}(s)}{\Delta q(s)}=\frac{K_{q_{0}}}{T_{q_{0}} \cdot s+1},
$$

where $\mathrm{T}_{\mathrm{qo}}-$ mean value of time constant of aeration tank for load-output link, min; $\Delta \mathrm{C}_{\mathrm{q}}(\mathrm{s})$ - Laplace transform of oxygen concentration change as a function of aeration tank load change, $\mathrm{g} / \mathrm{m}^{3} ; \Delta \mathrm{q}(\mathrm{s})$ - Laplace transform of load change, $\mathrm{g} / \mathrm{min}$

Time constants $\mathrm{T}_{\mathrm{ao}}$ and $\mathrm{T}_{\mathrm{qo}}$ were calculated applying the appropriate expressions from the publication [9]:

$$
\begin{aligned}
& T_{a_{o}}=\frac{V_{a} \cdot k_{10}\left(h, \lambda_{d 0}, \sigma_{s}\right)}{L_{g 0} \cdot k_{2}\left(T_{0}, h\right)}=\frac{1200 \cdot 1.12}{60 \cdot 1.53} \approx 15 \mathrm{~min}, \\
& T_{q_{o}}=\frac{V_{a} \cdot C_{0} \cdot k_{2}\left(T_{0}, h\right)}{q_{0} \cdot k_{10}\left(h, \lambda_{d 0}, \sigma_{s}\right)}=\frac{1200 \cdot 2 \cdot 1.53}{900 \cdot 1.12} \approx 4 \mathrm{~min},
\end{aligned}
$$

where $V_{\mathrm{a}}=1200 \mathrm{~m}^{3}$ - wastewater volume in aeration tank.

Block diagram, compiled in SIMULINK for transient process simulation using stationary model of wastewater aeration tank is presented in Fig.1. The model consists of transfer functions $(5,6)$ with invariable sensitivity coefficients $\mathrm{K}_{\mathrm{ao}}=0.18\left(\mathrm{~g} / \mathrm{m}^{3}\right) /\left(\mathrm{m}^{3} / \mathrm{min}\right), \mathrm{K}_{\mathrm{qo}}=-0.012\left(\mathrm{~g} / \mathrm{m}^{3}\right) /\left(\mathrm{m}^{3} / \mathrm{min}\right)$ and mean time constants $\mathrm{T}_{\mathrm{ao}}=15 \mathrm{~min}, \mathrm{~T}_{\mathrm{qo}}=4 \mathrm{~min}$.

\section{B. Self - tuning Non-stationary Model of Wastewater Aeration}

Actually, the wastewater aeration tank is a non-stationary object because of the variable transfer coefficients $K_{a}\left(L_{g}, q\right)$, $\mathrm{K}_{\mathrm{q}}\left(\mathrm{L}_{\mathrm{g}}\right)$ and the process inertia time constants $\mathrm{T}_{\mathrm{a}}=\mathrm{f}\left(\mathrm{L}_{\mathrm{g}}\right), \mathrm{T}_{\mathrm{q}}=\mathrm{f}$ $(q, C)$, which change during the oxygen transfer transient process. Since they are variable, transfer coefficients will be called as the sensitivity indexes and time constants - as the inertia indexes. 


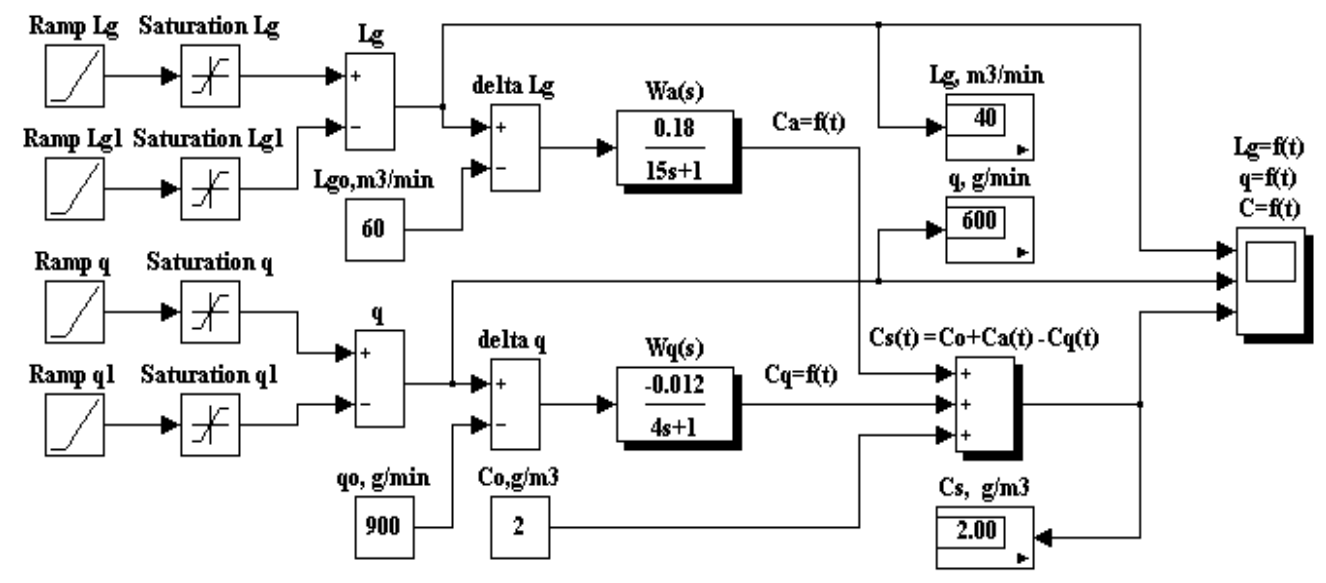

Fig. 1. Block-diagram in SIMULINK of a stationary model of the wastewater aeration tank with mean values of transfer coefficients $\mathrm{K}_{\mathrm{ao}}=0.18\left(\mathrm{~g} / \mathrm{m}^{3}\right) /$ $\left(\mathrm{m}^{3} / \mathrm{min}\right), \mathrm{K}_{\mathrm{qo}}=-0.012\left(\mathrm{~g} / \mathrm{m}^{3}\right) /\left(\mathrm{m}^{3} / \mathrm{min}\right)$ and time constants $\mathrm{T}_{\mathrm{ao}}=15 \mathrm{~min}, \mathrm{~T}_{\mathrm{qo}}=4 \mathrm{~min}$ for oxygen concentration simulation under regulated air supply $\mathrm{L}_{\mathrm{g}}(\mathrm{t})$ and variable load $\mathrm{q}(\mathrm{t})$.

Expressions for automatic calculation of sensitivity and inertia indexes, as the functions of variable parameters, during transient process simulation are as follows:

$$
\begin{aligned}
& K_{a}\left(L_{g}, q\right)=\frac{q \cdot k_{1}\left(h, \lambda_{d}, \sigma_{s}\right)}{L_{g}{ }^{2} \cdot k_{2}\left(T_{0}, h\right)}, K_{q}\left(L_{g}\right)=-\frac{k_{1}\left(h, \lambda_{d}, \sigma_{s}\right)}{L_{g} \cdot k_{2}\left(T_{0}, h\right)}, \\
& T_{a}\left(L_{g}\right)=\frac{V_{a} \cdot k_{1}\left(h, \lambda_{d}, \sigma_{s}\right)}{L_{g} \cdot k_{2}\left(T_{0}, h\right)}, T_{q}(q, C)=\frac{V_{a} \cdot C \cdot k_{2}\left(T_{0}, h\right)}{q \cdot k_{1}\left(h, \lambda_{d}, \sigma_{s}\right)}
\end{aligned}
$$

Coefficient $\mathrm{k}_{1}\left(\mathrm{~h}, \lambda_{\mathrm{d}}, \sigma_{\mathrm{s}}\right)$ is a function of variable $\lambda_{\mathrm{d}}$. Though $\mathrm{k}_{1}$ changes only $\pm 3 \%$ of $\mathrm{k}_{1 \mathrm{o}}$ within $\lambda_{\mathrm{d}}$ alteration range, it can be assumed for modelling purposes that $\mathrm{k}_{1}=\mathrm{k}_{1 \mathrm{o}}=1.12$.

Applying Laplace transforms, the mathematical model for oxygen concentration $\mathrm{C}_{\mathrm{n}}(\mathrm{t})$ transient process simulation in aeration tank has been obtained:

$$
\begin{gathered}
C_{n}(s)=W_{a n}(s) \cdot \Delta L_{g}(s)+W_{q n}(s) \cdot \Delta q(s)+C_{0}, \\
W_{a n}(s)=\frac{K_{a}\left(L_{g}, q\right)}{T_{a}\left(L_{g}\right) \cdot s+1}, \quad W_{q n}(s)=\frac{K_{q}\left(L_{g}\right)}{T_{q}(q, C) \cdot s+1}
\end{gathered}
$$

where $\mathrm{C}_{\mathrm{n}}(\mathrm{s})$ - Laplace transform of oxygen concentration of a non-stationary model; $\mathrm{W}_{\mathrm{an}}$ and $\mathrm{W}_{\mathrm{qn}}$ - transfer functions of an input impact channel and a load impact channel.

It is impossible to solve the given equation (11) analytically because of non-stationary transfer functions of the oxygen transfer transient process. Further on, it will be shown how to solve a problem virtually by using SIMULINK.

\section{OXYGEN CONCENTRATION TRANSIENT PROCESS MODELLING IN SIMULINK}

\section{A. Development of Adaptive Self-tuning Virtual Model}

The block-diagram of the adaptive self-tuning model for simulation of transient process of oxygen concentration $\mathrm{C}_{\mathrm{n}}(\mathrm{t})$ in the wastewater aeration tank, described by equation (11) is shown in Figure 2. It consists of several modulus for automatic calculations and simulation: " $\mathrm{K}_{\mathrm{a}}$ calculation module" - for calculation of wastewater aeration tank response sensitivity on pneumatic aeration rate $\Delta \mathrm{L}_{\mathrm{g}}(\mathrm{t})$, as a function of air blower variable capacity $\mathrm{L}_{\mathrm{g}}(\mathrm{t})$ and variable oxygen consumption for waste processing $\mathrm{q}(\mathrm{t})$, and " $\mathrm{K}_{\mathrm{q}}$ calculation module" - for calculation of wastewater aeration tank response sensitivity on oxygen consumption rate $\Delta \mathrm{q}(\mathrm{t})$ as non-linear function of air blower variable capacity $\mathrm{L}_{\mathrm{g}}\left(\mathrm{t}\right.$ ) (formulas 9); " $\mathrm{T}_{\mathrm{a}}$ calculation module" - for calculation of wastewater aeration tank response inertia on pneumatic aeration rate $\Delta \mathrm{L}_{\mathrm{g}}(\mathrm{t})$ as non-linear function of air blower variable capacity $\mathrm{L}_{\mathrm{g}}$, $(\mathrm{t})$, and " $\mathrm{T}_{\mathrm{q}}$ calculation module" - for calculation of wastewater aeration response inertia on oxygen consumption rate $\Delta \Delta \mathrm{q}(\mathrm{t})$ as a function of oxygen consumption for wastes oxidation $\mathrm{q}(\mathrm{t})$ and dissolved oxygen concentration $\mathrm{C}_{\mathrm{n}}(\mathrm{t})$ in wastewater (formulas 10).

The block-diagram - "Self-tuning transfer function of $\mathrm{L}_{\mathrm{g}}$ direct impact" consists of: " $\mathrm{K}_{\mathrm{a}}$ calculation module", " $\mathrm{T}_{\mathrm{a}}$ calculation module"; " $1 / \mathrm{s}$ " $\mathrm{x}$ " $1 / \mathrm{T}_{\mathrm{a}}$ " - an integrator with unit feedback " 1 ", and forms a channel for modelling of oxygen transient value $\Delta \mathrm{C}_{\mathrm{a}}(\mathrm{t})$ as a function of aeration rate $\Delta \mathrm{L}_{\mathrm{g}}(\mathrm{t})$.

The block-diagram - "Self-tuning transfer function of $\mathrm{q}$ direct impact" is composed of: " $\mathrm{K}_{\mathrm{q}}$ calculation module", " $\mathrm{T}_{\mathrm{q}}$ calculation module"; " $1 / \mathrm{s}$ " $\mathrm{x}$ " $1 / \mathrm{T}_{\mathrm{q}}$ " - an integrator with unit feedback " 1 ", and forms a channel for modelling of oxygen concentration transient component $\Delta \mathrm{C}_{\mathrm{q}}(\mathrm{t})$ as a function of variable load $\Delta \mathrm{q}(\mathrm{t})$

B. Block-diagram for comparative research of Stationary and Non-stationary Models

The simulation block-diagram (Fig.3) of the wastewater aeration tank consists of "Stationary model" and "Nonstationary model". "Stationary model" is compiled as a subsystem according to block-diagram of linear stationary model with constant sensitivity and inertia indexes (Fig.1). "Non-stationary model" is compiled according to the blockdiagram of adaptive self-tuning model with variable time dependent sensitivity and inertia indexes (Fig.2), calculated by modulus " $\mathrm{K}_{\mathrm{a}}$ ", " $\mathrm{K}_{\mathrm{q}}$ ", " $\mathrm{T}_{\mathrm{a}}$ " and " $\mathrm{T}_{\mathrm{q}}$ " during a transient process. 


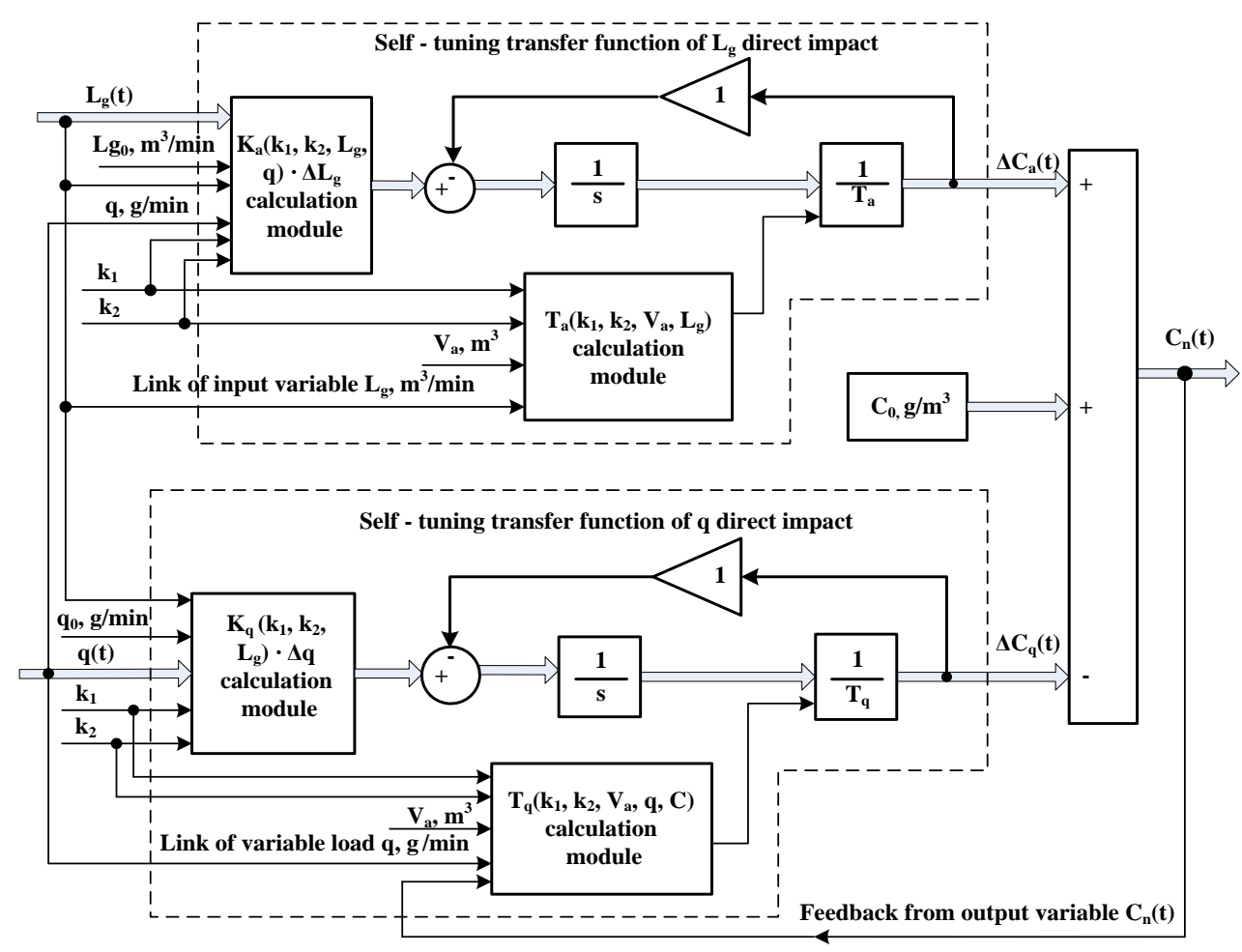

Fig. 2. Block-diagram of adaptive self-tuning model of wastewater aeration tank with on-line links from variable air supply - $\mathrm{L}_{\mathrm{g}}(\mathrm{t})$ and variable oxygen expenditure for wastes oxidation $-\mathrm{q}(\mathrm{t})$, and feedback from variable oxygen concentration $-\mathrm{C}_{\mathrm{n}}(\mathrm{t})$ to the modules of sensitivity and inertia indexes calculation

Constant linear growing and linear decreasing input variable $\mathrm{L}_{\mathrm{g}}$ and load $\mathrm{q}$ were used for the transient process simulation, formed by signal generators (Ramp), signal limitation blocks (Saturation) and (Sum-blocks). Fixed coefficients and parameters $\left(\mathrm{k}_{1}, \mathrm{k}_{2}, \mathrm{~V}_{\mathrm{a}}\right)$, and initial conditions $\left(\mathrm{L}_{\mathrm{go}}, \mathrm{q}_{0}, \mathrm{C}_{0}\right)$ are formed by constant signal generators (Constant). Digital displays are set up for numeric values visualization: $\mathrm{L}_{\mathrm{g}}-$ aeration rate, $\mathrm{m}^{3} / \mathrm{min} ; \mathrm{q}$ - oxygen expenditure as a load, $\mathrm{g} / \mathrm{min}$; $\mathrm{C}_{\mathrm{s}}$ and $\mathrm{C}_{\mathrm{n}}$ - oxygen concentration for stationary and nonstationary models, $\mathrm{g} / \mathrm{m}^{3} ; \mathrm{K}_{\mathrm{a}}$ - sensitivity index of the aeration impact channel, $\left(\mathrm{g} / \mathrm{m}^{3}\right) /\left(\mathrm{m}^{3} / \mathrm{min}\right) ; \mathrm{K}_{\mathrm{q}}$ - sensitivity index of the load impact channel, $\left(\mathrm{g} / \mathrm{m}^{3}\right) /(\mathrm{g} / \mathrm{min}) ; \mathrm{T}_{\mathrm{a}}, \mathrm{T}_{\mathrm{q}}$ - inertia indexes of aeration and load impact channels.

For visualization of variable sensitivity and inertia indexes $\left(\mathrm{K}_{\mathrm{a}}(\mathrm{t}), \mathrm{K}_{\mathrm{q}}(\mathrm{t}), \mathrm{T}_{\mathrm{a}}(\mathrm{t}), \mathrm{T}_{\mathrm{q}}(\mathrm{t})\right)$ and input, load and output transient characteristics $\left(\mathrm{L}_{\mathrm{a}}(\mathrm{t}), \mathrm{q}(\mathrm{t}), \mathrm{C}_{\mathrm{s}}(\mathrm{t}), \mathrm{C}_{\mathrm{n}}(\mathrm{t})\right)$, the scopes are set up.

\section{DISCUSSION AND RESULTS}

Simulation results of the sensitivity and inertia indexes for stationary and non-stationary models under constant and linear changing input impact and load are presented in Figure 4.

Constant parameters of the stationary model $\left(\mathrm{K}_{\mathrm{ao}}=0.18\right.$ $\left(\mathrm{g} / \mathrm{m}^{3}\right) /\left(\mathrm{m}^{3} / \mathrm{min}\right), \mathrm{K}_{\mathrm{qo}}=-0.012\left(\mathrm{~g} / \mathrm{m}^{3}\right) /(\mathrm{g} / \mathrm{min}), \mathrm{T}_{\mathrm{ao}}=15 \mathrm{~min}, \mathrm{~T}_{\mathrm{qo}}=4$ $\mathrm{min})$ are initial conditions of the non-stationary model. Initial sensitivity and inertia indexes have been obtained using initial values of: wastewater aeration capacity $-\mathrm{L}_{\mathrm{go}}=60 \mathrm{~m}^{3} / \mathrm{min}$; oxygen expenditure as a load $-\mathrm{q}_{0}=900 \mathrm{~g} / \mathrm{m}^{3}$; oxygen concentration $-\mathrm{C}_{0}=2 \mathrm{~g} / \mathrm{m}^{3}$ (Fig.5).
Simulation shows that sensitivity index $\mathrm{K}_{\mathrm{a}}$ of the wastewater aeration tank changes from the minimum value $\mathrm{K}_{\mathrm{a} \text { min }}=0.07$ $\left(\mathrm{g} / \mathrm{m}^{3}\right) /\left(\mathrm{m}^{3} / \mathrm{min}\right)$ at maximum of air supply capacity $\mathrm{L}_{\mathrm{g} \max }=80$ $\mathrm{m}^{3} / \mathrm{min}$ to the maximum $\mathrm{K}_{\mathrm{a} \max }=0.28\left(\mathrm{~g} / \mathrm{m}^{3}\right) /\left(\mathrm{m}^{3} / \mathrm{min}\right)$ at minimum of air supply capacity $\mathrm{L}_{\mathrm{gmin}}=40$

$\mathrm{m}^{3} / \mathrm{min}$ and $\mathrm{q}=600 \mathrm{~g} / \mathrm{min}=$ const. Therefore, $\mathrm{K}_{\mathrm{a}}$ changes the opposite way to $\mathrm{L}_{\mathrm{g}}$ change. Under given conditions, the sensitivity index $\mathrm{K}_{\mathrm{a}}$ changes up to $\pm 50 \%$ around the mean initial value $\mathrm{K}_{\mathrm{ao}}=0.18\left(\mathrm{~g} / \mathrm{m}^{3}\right) /\left(\mathrm{m}^{3} / \mathrm{min}\right)$. Likewise, the sensitivity and inertia index of load impact channel $\mathrm{K}_{\mathrm{q}}, \mathrm{T}_{\mathrm{q}}$ and the inertia index of aeration impact channel $\mathrm{T}_{\mathrm{a}}$ change substantially (Fig.4). Therefore, only the non-stationary model is able to adapt the variable indexes during a simulation process.

Simulated response of stationary and non-stationary models under equal initial conditions and similar input impact $\mathrm{L}_{\mathrm{g}}(\mathrm{t})$ and load $q(\mathrm{t})$ variability show that the transient characteristic of oxygen concentration $\mathrm{C}_{\mathrm{s}}=\mathrm{f}(\mathrm{t})$, if the simplified stationary model is used, substantially differs from that $C_{n}=f(t)$, which is obtained using the adaptive self-tuning non-stationary model (Fig.5). Larger difference between the oxygen concentration steady value of the non-stationary model $\left(C_{n}=6 \mathrm{~g} / \mathrm{m}^{3}\right)$ and the stationary model $\left(C_{s}=9.2 \mathrm{~g} / \mathrm{m}^{3}\right)$ occurs, if wastewater aeration intensity is maximal $\left(\mathrm{L}_{\mathrm{g} \max }=80 \mathrm{~m}^{3} / \mathrm{min}\right)$ because of noticeably lower sensitivity of aeration impact channel $\left(\mathrm{K}_{\mathrm{a} \text { min }}=0.07\right.$ $\left(\mathrm{g} / \mathrm{m}^{3}\right) /\left(\mathrm{m}^{3} / \mathrm{min}\right)$, in comparison with the initial mean value $\left(\mathrm{K}_{\mathrm{ao}}\right.$ $=0.18\left(\mathrm{~g} / \mathrm{m}^{3}\right) /\left(\mathrm{m}^{3} / \mathrm{min}\right)$.

As the wastewater aeration tank sensitivity and inertia indexes change substantially, only the adaptive self-tuning nonstationary model ensures appropriate accuracy of oxygen concentration modelling in the wastewater aeration tank. 


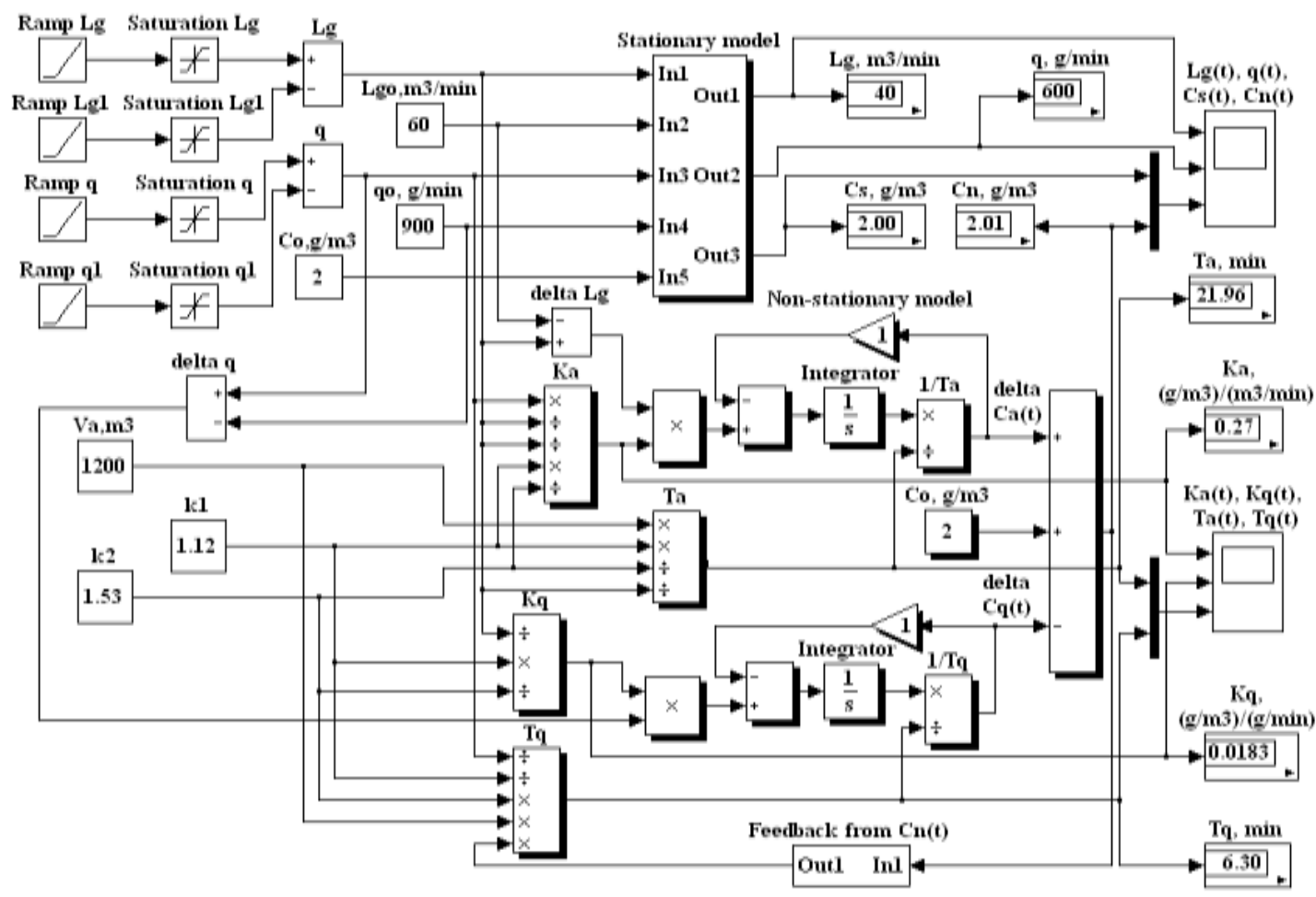

Fig. 3. Block - diagram in SIMULINK of stationary and non-stationary models for dissolved oxygen concentration simulation in wastewater aeration tank.

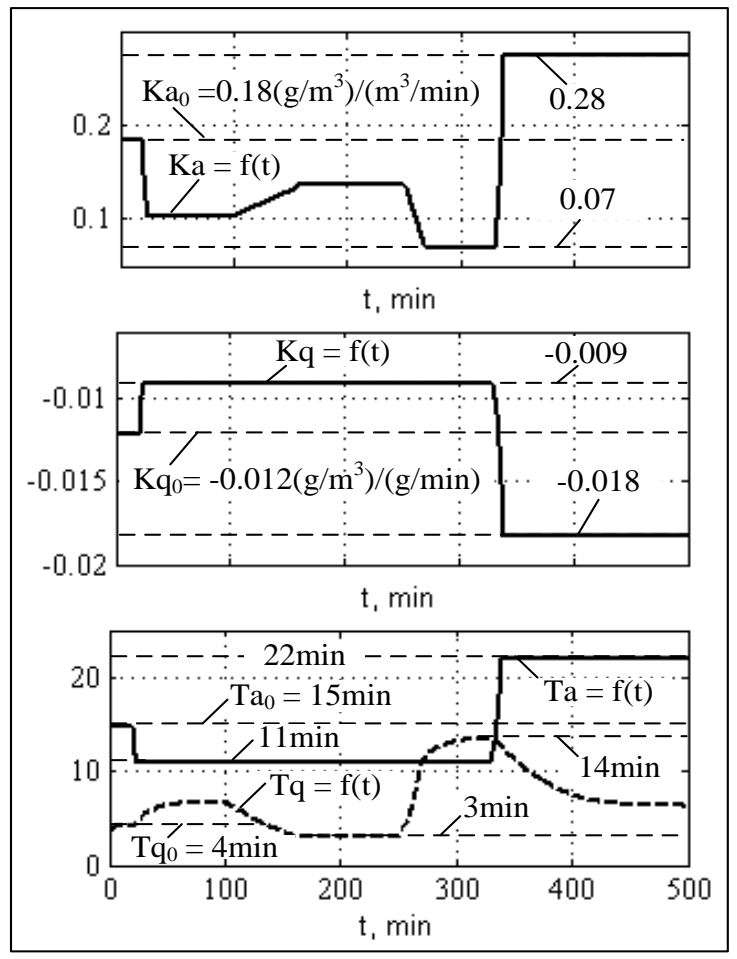

Fig. 4. Characteristics of sensitivity and inertia indexes for the stationary model $\left(\mathrm{K}_{\mathrm{ao}}=\right.$ const., $\mathrm{K}_{\mathrm{qo}}=$ const., $\mathrm{T}_{\mathrm{ao}}=$ const., $\mathrm{T}_{\mathrm{qo}}=$ const. $)$ and for the nonstationary model $\left(\mathrm{K}_{\mathrm{a}}=\mathrm{f}(\mathrm{t}), \mathrm{K}_{\mathrm{q}}=\mathrm{f}(\mathrm{t}), \mathrm{T}_{\mathrm{a}}=\mathrm{f}(\mathrm{t}), \mathrm{T}_{\mathrm{q}}=\mathrm{f}(\mathrm{t})\right.$ under constant and linear changing input impact $\mathrm{L}_{\mathrm{g}}=\mathrm{f}(\mathrm{t})$ and oxygen expenditure as a load $\mathrm{q}=\mathrm{f}(\mathrm{t})$.

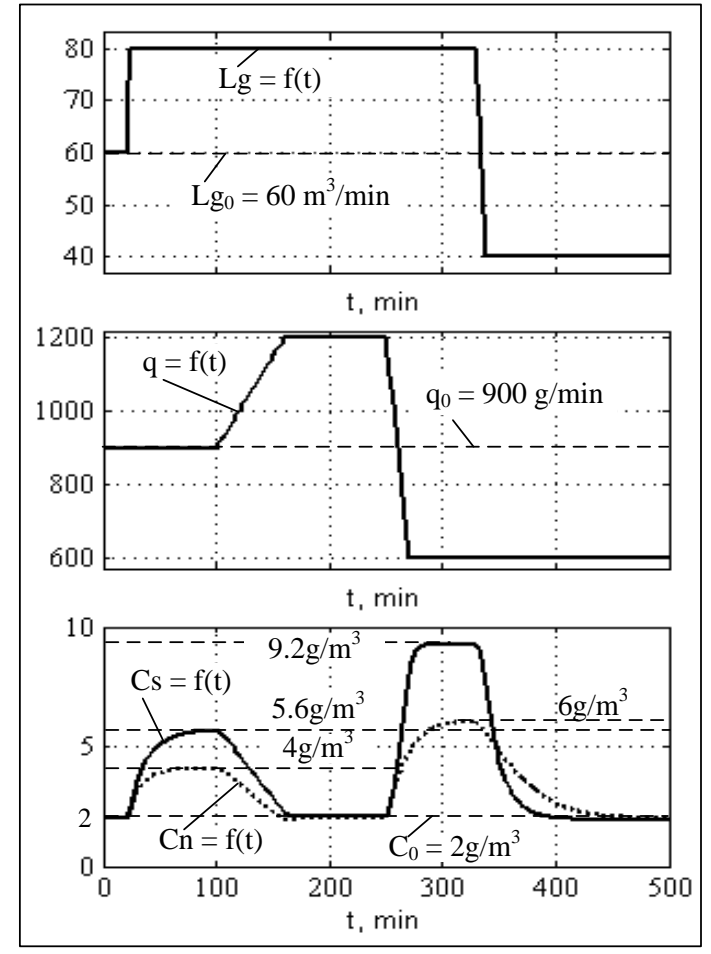

Fig. 5. Simulated characteristics of oxygen concentration for the stationary model $\mathrm{C}_{\mathrm{s}}=\mathrm{f}(\mathrm{t})$ and for the non-stationary model $\mathrm{C}_{\mathrm{n}}=\mathrm{f}(\mathrm{t})$ under constant and linear changing input impact $\mathrm{L}_{\mathrm{g}}=\mathrm{f}(\mathrm{t})$ and oxygen expenditure as a load $q=f(t)$. 


\section{CONCLUSIONS}

For the oxygen concentration transient process virtual analyses in the wastewater aeration tank, whose sensitivity and inertia indexes change substantially depending on input, output and load variables, the adaptive self-tuning up nonstationary virtual model should be developed applying on-line links from variables to modulus for automatic re-calculation of sensitivity and inertia indexes of the model during all simulation processes.

Simulation results show that the non-stationary model of the wastewater aeration tank, which takes into account change of sensitivity and inertia indexes during the simulation process, increases the modelling accuracy of the oxygen transfer transient process and reaches a steady final value of oxygen concentration, which is lower by $50 \%$, in comparison with the result obtained from using the simplified stationary model.

\section{REFERENCES}

1. Ingildsen, P., Olsson, G., Yuan, Z. A Hedging Point Strategy Balancing Effluent Quality, Economy and Robustness in the Control of Wastewater Plants. Proceedings ICA 2001 Vol. 2, Malmo, Sweden, p. 449-456, June 3-7, 2001.

2. Ferrer, J. Energy Saving in the Aeration Process by Fuzzy Logic Control. Wat. Sci. Tech., Vol.38, No. 3, 1998, p. $209-217$.

3. Sniders, A. Simulation and energy-saving control in wastewater aeration system. In: The $3^{\text {rd }}$ International Conference on Ecology and Agricultural Machinery, Saint-Petersburg, June 2-4, 2002. Proceedings Vol. II, Saint-Petersburg, 2002, p. 294-302.

4. Sniders A. The Expenditure of Electrical Energy for Communal sewage purification. Baltic Electrical Engineering review, Vilnius, №2 (6), 1997, p. 29-32.

5. Sniders, A., Laizans, A. Invariant Control of Wastewater Aeration. In: The $1^{\text {th }}$ International Internet Conference IETA 2005, TENE 2005 and EIAE 2005 on Advances in Computer, Information, and Systems Sciences and Engineering, Bridgeport, USA, December 17-20, 2005. Proceedings, Dordrecht: Springer, 2006, p.99-103.

6. Jorgensen, S. E. Fundamentals of Ecological Modelling, $2^{\text {nd }}$ ed. Amsterdam: Elsevier Science B.V., 1994, 663 p.

7. Sniders, A. Static indices of wastewater pneumatic aeration. Proceedings of the Latvia Univ. of Agric., Jelgava, Vol. (8), 1997, p. 43-47.

8. Sniders, A. Transient process modelling in wastewater aeration unit. In: The International Conference on Environment \&Technology \&
Resources, Rezekne High School, June 20-21, 2003. Proceedings, Rezekne, 2003, p. 268-274.

9. Sniders, A., Laizans, A. Computer aided modelling of wastewater aeration. In: The $3^{\text {rd }}$ International Scientific Conference on Rural Development, Lithuaninan University of Agriculture, Kaunas, November 8 -10, 2007. Proceedings Vol. 3, Book 2. Kaunas: Academia, 2007, p. 227. - 231 .

10. Sniders, A. Adaptive Self-Tuning up Model for Non-Stationary Process Simulation. In: The $9^{\text {th }}$ International Scientific Conference on Engineering for Rural Development, Latvia University of Agriculture, Jelgava, May 27-28, 2010. Proceedings. Jelgava: LUA, 2010, p. 192199.

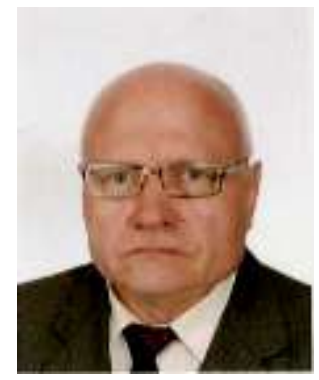

Andris Sniders. Dr.hab.sc.ing., professor, Latvia University of Agriculture (LUA) Institute of Agricultural Energetics (IAE). Professor Andris Sniders has been part of academic staff of Faculty of Engineering (FE) LUA since 1972 and director of IAE (1999 2007). He has an Electrical Engineer Diploma (Riga Polytechnic Institute -1972), Candidate degree in Technical Sciences (Celyabinsk, Russia -1982), PhD degree (1992) and Doctor Habilitus degree (1993) in Agricultural power engineering - Jelgava, Latvia, FE LUA

He has participated in several projects, related to electrical and heat power engineering, waste water treatment control, energy efficiency and study process perfection, as well as is an author of more than 150 publications, incl., 4 books and 12 teaching appliances. The main research area is automatic control and modelling of waste water aeration and power supply engineering systems, virtual modelling of non-stationary technological units and systems.

Address: 5 J.Cakstes blvd., LV-3001, Jelgava, Latvia

Phone: +37163022242

E-mail: andris.sniders@1lu.1v

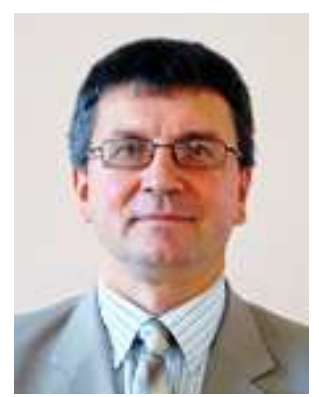

Aigars Laizans, Dr.sc.ing, assistant professor of the Institute of Agricultural Energetics at Latvia University of Agriculture. Research interests: automatic control and modelling of waste water aeration engineering systems, renewable energy sources and economics of power engineering.

E-mail: aigars.laizans@gmail.com

Andris Šnīders, Aigars Laizāns. Notekūdenu aerācijas tvertnes adaptīvais modelis.

Tiek apskatīta skābekḷa koncentrācijas izmaiņas procesa virtuālā modelēšana notekūdeṇu aerācijas tvertnē, izmantojot MATLAB/SIMULINK tehnoloǵiju. Notekūdenu aerācijas tvertne ir nestacionārs tehnoloǵisks objekts ar laikā main̄̄giem jutības un inerces rādītājiem, kurus būtiski iespaido sekojoši mainīgi faktori: 1) ieejas regulējošā iedarbe - caur difuzoriem pievadītais gaisa daudzums notekūdenu piespiedu pneimatiskās aerācijas procesā - $\mathrm{L}_{\mathrm{g}}(\mathrm{t})$ ( $\mathrm{m}^{3} / \mathrm{m}_{\mathrm{i}}$ ); 2 ) mainīgā slodze uz aerācijas tvertni - notekūdeņos izšk̄īdušā skābekḷa patēriņš organisko piemaisījumu oksidācijai- q(t) (g/min); 3) izejas stabilizējamais lielums notekūdenos izškīdušā skābekla koncentrācija - C(t) $\left(\mathrm{g} / \mathrm{m}^{3}\right)$. Skābekla koncentrāciju statiskā režīmā apraksta nelineāra daudzfaktoru funkcija $(1)$, bet dinamiskā režīmā - nestacionāri diferenciālvienādojumi ar laikā mainīgiem koeficientiem, kuru precīza atrisināšana analītiski nav iespējama. Var izmantot tuvinātas metodes, izvirzot daudzfaktoru funkciju Teilora rindā parciālo atvasinājumu veidā (2) un pienemot nemainīgus jutības $(3,4)$ un inerces $(7,8)$ rādītājus ierobežotā darba apgabalā. Tad iegūst stacionāra model̦a pārvades funkcijas ar konstantiem koeficientiem $(5,6)$. Šāda metode neizbēgami rada modelēšanas kḷūdas. Darba mērḳis - salīdzināt aerācijas tvertnes tuvināto stacionāro modeli (1.att.) ar nestacionāro modeli (3.att.), izmantojot virtuālās analīzes metodi SIMULINK vidē. Nestacionārs adaptīvs virtuālais modelis ar parametru pašnoskanošanās spēju pārejas procesa simulācijas laikā iegūts, izveidojot tiešas saites no mainīgajām iedarbēm $\operatorname{Lg}(\mathrm{t})$, q(t) un izejas mainīgā lieluma $\mathrm{C}(\mathrm{t})$ uz jutības rādītāju $\mathrm{K}_{\mathrm{a}}, \mathrm{K}_{\mathrm{q}}$ (9) un inerces rādītāju $\mathrm{T}_{\mathrm{a}}$, $\mathrm{T}_{\mathrm{q}}$ (10) aprēķina moduļiem, kā arī veidojot pašnoskanojošos pārvades funkciju (12) blokshēmas ar integratoriem, kas aptverti ar negatīvām vieninieka atgriezeniskajām saitēm (2.att). Modelēšanas rezultāti parāda, ka notekūdenu aerācijas procesa norises apgabalā tā jutības un inerces rādītāji mainās plašās robežās (4.att.) un būtiski iespaido skābekḷa koncentrācijas modelēšanas rezultātu (5.att.). Tādēl skābekḷa koncentrācijas izmaiṇas atbilstību reālajam procesam aerācijas tvertnē var nodrošināt tikai nestacionārs modelis. 